\title{
Kajian Efektivitas Penggantian Alat Tangkap Cantrang Menjadi Gillnet Millenium di Banyutowo, Pati, Jawa Tengah
}

\section{The Effectiveness of Fishing Gear's Replacement from Cantrang into Gillnet Millennium at Banyutowo, Pati Residence}

\author{
Neneng Evy Yulieny ${ }^{\mathrm{a}}$, Achmad Fahrudin ${ }^{\mathrm{b}}$, Nimmi Zulbainarni ${ }^{\mathrm{c}}$ \\ a Inspektorat Jenderal Kementerian Kelautan dan Perikanan, Gedung Mina Bahari IV, Jakarta, 10110, Indonesia \\ ${ }^{\mathrm{b}}$ Program Departemen Manajemen Sumberdaya Perairan, Fakultas Perikanan dan Ilmu Kelautan, Institut Pertanian Bogor, Kampus \\ IPB Darmaga, Bogor, Jawa Barat 16128, Indonesia \\ ${ }^{\mathrm{c}}$ Sekolah Bisnis Institut Pertanian Bogor. Kampus IPB Gunung Gede Bogor, 16128, Indonesia
}

\section{Article Info:}

Received: 10 - 07 - 2019

Accepted: $17-09-2019$

Keywords:

Banyutowo, Cantrang, Gillnet millenium,

Replacement Fishing Gear

Corresponding Author:

Neneng Evy Yulieny

Inspektorat Jenderal

Kementerian Kelautan dan

Perikanan, Jakarta

Tel. 081293182145

Email: evy.neneng@gmail.com

\begin{abstract}
This study's background was based on the prohibition of cantrang's operation. To reduce impact of this ban, the Government was replacing cantrangs with another fishing gears which are considered more environmentally friendly. In Banyutowo, Pati Residence, "cantrang" was replaced with Gillnet Millennium. This study aims to determine the pattern of fishing season of some of the dominant fish species caught around Banyutowo and to analyze the effectiveness of replacing fishing gear, from cantrangs into gillnet millenium at Banyutowo. Based on the analysis of fishing season patterns and types of fishing gear for seven months a year (January, February, March, April, May, October and December) it is known that cantrang can catch more types of fish compared to gillnet, whereas gillnet is more selective in catch fish compared to cantrang. The evaluation of the effectiveness of replacing cantrang into the gillnet millennium in Banyutowo at the process stage shows ineffective results, and at the output stage shows very ineffective results. The change of fishing gear needs to consider its suitability with the fishing fleet used in addition to assistance so that the fishermen who receive the program are proficient in using the fishing gear.
\end{abstract}

How to cite (CSE Style $8^{\text {th }}$ Edition):

Yulieny NE, Fahrudin A, Zulbainarni N. 2019. Kajian Efektivitas Penggantian Alat Tangkap Cantrang Menjadi Gillnet Millenium di Banyutowo, Pati, Jawa Tengah. JPSL 10(1): 34-42. http://dx.doi.org/10.29244/jpsl.10.1.34-42.

\section{PENDAHULUAN}

Potensi perikanan di perairan Indonesia harus tetap dijaga agar dapat dikelola untuk meningkatkan kesejahteraan masyarakat nelayan Indonesia (Ruchimat, 2013 dalam Hermanto et al., 2019), namun beberapa wilayah di Indonesia telah mengalami penurunan sumber daya, antara lain Pantai Utara Jawa Tengah terindikasi telah mengalami over fishing, dimana salah satu penyebabnya adalah tekanan penangkapan yang didominasi oleh perikanan tangkap skala kecil yang banyak beroperasi di perairan pantai (Triarso, 2013). Simbolon dan Girsang (2009) dalam Hidayat et al. (2019) mengemukakan bahwa penurunan stok ikan dapat diantipasi dengan menghindari tangkapan kategori tidak layak tangkap secara biologis, penggunaan alat tangkap selektif hanya terhadap ikan kategori layak tangkap secara biologis, serta perencanaan operasi penangkapan ikan pada musim tertentu ketika ikan kategori layak tangkap dominan di perairan, dan pengendalian jumlah upaya penangkapan sesuai dengan potensi lestari (carrying capacity).

Terkait dengan upaya untuk mengantisipasi penurunan stok ikan tersebut serta pencapaian visi pembangunan sektor kelautan dan perikanan di Indonesia, yaitu mewujudkan pengelolaan sumberdaya kelautan dan perikanan yang berkelanjutan antara lain dengan menghentikan tindakan perusakan eksploitasi 
dan pengelolaan yang tidak ramah lingkungan, pemerintah telah menerbitkan Peraturan Menteri Kelautan dan Perikanan No. 2 Tahun 2015 tentang Pelarangan Alat Penangkapan Ikan Pukat Hela dan Pukat Tarik (Seine Nets), termasuk di dalamnya alat tangkap cantrang. Terbitnya peraturan ini berdasarkan pada temuan di lapangan bahwa para nelayan memodifikasi alat tangkap tersebut sehingga menyebabkan alat tangkap tersebut tidak ramah lingkungan (Nababan et al., 2018). Di sisi lain, pelarangan penggunaan cantrang ini menimbulkan gejolak sosial di masyarakat dan mempengaruhi perekonomian masyarakat (Zulbainarni et al., 2016). Untuk mengatasi gejolak sosial yang terjadi, Kementerian Kelautan dan Perikanan berupaya melakukan peralihan alat tangkap cantrang menjadi alat tangkap ramah lingkungan, yaitu gillnet millennium. Salah satu lokasi penerapan kebijakan ini adalah di Kabupaten Pati, Provinsi Jawa Tengah, tepatnya di Pangkalan Pendaratan Ikan (PPI) Banyutowo. Dibutuhkan suatu penelitian yang bertujuan menganalis pola musim penangkapan beberapa jenis ikan yang ditangkap menggunakan cantrang dan gillnet; serta menganalisis efektivitas penggantian cantrang menjadi alat tangkap gillnet millenium, khususnya di PPI Banyutowo Kab. Pati tersebut.

\section{METODE}

\section{Lokasi dan Waktu Penelitian}

Penelitian dilakukan di PPI Banyutowo, Kec. Dukuhseti Kabupaten Pati, Propinsi Jawa Tengah, mulai dari bulan Desember 2017 hingga Januari 2018.

\section{Metode Pengumpulan Data}

Data primer diperoleh dari hasil wawancara dengan para responden yang ditentukan dengan teknik purposive sampling, yaitu nelayan yang menerima penggantian cantrang menjadi gillnet millennium. Jumlah responden adalah 16 orang atau $88.69 \%$ dari seluruh penerima penggantian cantrang dengan gillnet millennium (18 orang). Adapun data sekunder, yaitu data runtun waktu hasil tangkapan (bulanan) beberapa jenis ikan yang dominan tertangkap oleh nelayan cantrang dan gillnet selama tahun 2009-2017, diperoleh dari instansi terkait Dinas Perikanan dan Kelautan Kabupaten Pati dan Balai Besar Penangkapan Ikan (BPPI) Semarang.

\section{Metode Analisis Data}

\section{Analisis Pola Musim Penangkapan Ikan}

Data time series bulanan hasil tangkapan selama tahun 2009-2017 tersebut dianalisis menggunakan analisis deret waktu terhadap data hasil tangkapan (Dajan, 1986).

Kriteria Indeks Musim Penangkapan (IMP) (Simarmata et al., 2014)

IMP $<50 \% \quad:$ musim paceklik

$50 \%<\mathrm{IMP}<100 \% \quad$ : bukan musim penangkapan (BMP)

IMP $>100 \% \quad:$ musim penangkapan

Untuk mengetahui ada atau tidaknya perbedaan IMP berdasarkan jenis ikan dan bulan, selanjutnya dilakukan analisis sidik ragam/ Analisis of variance (Anova) terhadap hasil IMP. Analisis dilakukan dengan bantuan Microsoft excel.

Hipotesis yang akan diuji sebagai berikut:

$\mathrm{H}_{01} \quad$ : Tidak terdapat perbedaan nyata IMP beberapa jenis ikan di Banyutowo berdasarkan bulan

$\mathrm{H}_{11} \quad$ : Terdapat perbedaan nyata IMP beberapa jenis ikan di Banyutowo bulan berdasarkan bulan

$\mathrm{H}_{02} \quad$ : Tidak terdapat perbedaan nyata IMP bulanan beberapa jenis ikan di Banyutowo

$\mathrm{H}_{12} \quad$ : Terdapat perbedaan nyata IMP bulanan beberapa jenis ikan di Banyutowo 


\section{Efektivitas Penggantian Cantrang dengan Gillnet Millenium}

Dalam penelitian ini akan dilakukan penilaian efektivitas dengan model evaluasi sistem analisis pada tahap proses dan keluaran (Wirawan, 2016). Dalam manajemen, sistem diformulasikan dalam bentuk linier produksi yang terdiri dari input, proses, keluaran, akibat dan pengaruh. Dari setiap segmen tersebut dapat dievaluasi untuk menentukan nilai dan manfaat keseluruhan sistem, dan dalam model evaluasi sistem analisis ini evaluasi pada setiap tahap dapat dilakukan terpisah (Wirawan, 2016).

Variabel penilaian efektivitas pada tahap proses meliputi apakah identifikasi dan validasi calon penerima sesuai ketentuan, apakah penerima mengetahui tujuan kegiatan, apakah telah mengikuti kegiatan sosialisasi, apakah penerima penggantian mengetahui mengenai alternatif alat tangkap pengganti, apakah penerima penggantian telah mengikuti pelatihan, dan apakah ada kegiatan pendampingan atau pemantauan setelah penggantian alat tangkap.

Variabel penilaian efektivitas pada keluaran/ouput penggantian cantrang menjadi gillnet millennium meliputi apakah penerima penggantian memilih gillnet millennium sebagai alat tangkap pengganti, pemanfaatan gillnet millennium sebagai alat tangkap pengganti, kemampuan merakit dan mengoperasikan gillnet millennium, kesesuaian perahu yang dimiliki untuk mengoperasikan gillnet millennium serta kesesuaian gillnet millennium untuk digunakan di perairan sekitar Banyutowo.

Analisis efektivitas kegiatan pada tahap proses dan keluaran dilakukan dengan nilai rasio antara realisasi dengan target kegiatan (\%), dengan rumus sebagai berikut:

$$
\text { Efektivitas kegiatan per tahap }=\frac{R}{T} X 100 \%
$$

Dimana:

$\mathrm{R}=$ Realisasi

$\mathrm{T}=$ Target

Acuan yang dipakai untuk mengukur efektivitas pada Tabel 2 menggunakan kriteria kuantitatif dengan pertimbangan (Arikunto dan Jabar 2008), tercantum pada Tabel 2.

Tabel 2 Kriteria tingkat efektivitas .

\begin{tabular}{cc}
\hline Nilai & Tingkat Efektivitas \\
\hline Di bawah $40 \%$ & Sangat tidak efektif \\
$40 \%-55.99 \%$ & Tidak efektif \\
$56 \%-65.99 \%$ & Cukup efektif \\
$66-79.99 \%$ & Efektif \\
Di atas $80 \%$ & Sangat efektif \\
\hline
\end{tabular}

\section{HASIL DAN PEMBAHASAN}

\section{Pola Musim Penangkapan Ikan}

Alat tangkap yang banyak dioperasikan di perairan sekitar Banyutowo adalah gillnet (198 unit) dan cantrang (21 unit) (Data Dinas Kelautan dan Perikanan Kab. Pati, 2017). Diketahui tujuh jenis ikan yang ditangkap oleh cantrang di Banyutowo, yaitu Kuniran (Upeneus sp), Pari (Dasyatis sp), Beloso (Sauryda sp), Manyung (Arius sp), Kuro (Eleutheronema tetradactylum), Tigawaja (Nibea sp) dan Cumi-cumi (Loligo sp), sedangkan gillnet hanya menangkap empat jenis ikan, yaitu manyung (Arius sp), kuro (Eleutheronema tetradactylum) dan Tigawaja (Nibea sp). Data time series sepanjang tahun 2009-2017 menunjukkan musim penangkapan tujuh jenis ikan di perairan Banyutowo berbeda-beda (Tabel 3). Rerata bulanan IMP ikan demersal dan cumi-cumi di perairan Banyutowo berkisar antara 75.20\%-136.58\% (Tabel 3), menunjukkan bahwa secara umum tidak ada bulan paceklik di Banyutowo (Gambar 2). Hasil penelitian sebelumnya di perairan Laut Jawa menunjukkan hasil yang serupa, dimana ikan demersal dan Cumi-cumi dapat ditangkap sepanjang tahun dan tidak nampak adanya perbedaan sebaran ikan demersal antara musim barat dan musim peralihan (Imron 2008, Priatna dan Natsir 2008).

36 
Bulan April (musim peralihan) merupakan musim penangkapan bagi sebagian besar jenis ikan yang dianalisis dalam penelitian ini, yaitu ikan Kuniran (Upeneus sp), Manyung (Arius sp), Pari (Dasyatis sp), Beloso (Sauryda sp), Tigawaja (Nibea sp) dan Cumi-cumi (Loligo sp). Musim peralihan ini merupakan masa yang paling disukai oleh nelayan untuk melakukan penangkapan ikan. Selain karena kecepatan angin di Laut Jawa pada bulan-bulan tersebut lebih rendah dibandingkan pada musim barat dan musim timur, juga karena ukuran ikan yang ditangkap lebih besar dibandingkan musim Barat (Priatna dan Natsir 2008).

Tabel 3 Indeks Musim Penangkapan Beberapa Jenis Ikan di PPI Banyutowo Tahun 2009-2017.

\begin{tabular}{cccccccccc}
\hline Bulan & \multicolumn{10}{c}{ IMP $(\%)$} \\
\cline { 2 - 10 } & Kuniran & Cumi & Pari & Beloso & Manyung & Kuro & Waja & Rerata & Ket \\
\hline Jan & 104.22 & 110.42 & 95.62 & 76.14 & 57.29 & 77.56 & 95.96 & $\mathbf{8 8 . 1 7}$ & BMP \\
Feb & 124.52 & 85.05 & 82.11 & 87.63 & 101.59 & 81.35 & 94.00 & $\mathbf{9 3 . 7 5}$ & BMP \\
Mar & 114.76 & 99.80 & 84.51 & 90.82 & 70.89 & 83.72 & 86.67 & $\mathbf{9 0 . 1 7}$ & BMP \\
Apr & 112.68 & 109.70 & 102.64 & 113.74 & 141.01 & 85.81 & 113.96 & $\mathbf{1 1 1 . 3 6}$ & MP \\
Mei & 116.28 & 139.44 & 140.32 & 132.02 & 49.52 & 81.81 & 90.67 & $\mathbf{1 0 7 . 1 5}$ & MP \\
Jun & 67.84 & 77.55 & 127.49 & 91.78 & 78.30 & 107.07 & 115.94 & $\mathbf{9 5 . 1 4}$ & BMP \\
Jul & 45.96 & 50.44 & 81.37 & 76.63 & 94.20 & 95.31 & 82.53 & $\mathbf{7 5 . 2 0}$ & BMP \\
Ags & 55.49 & 51.67 & 83.08 & 71.27 & 165.56 & 107.06 & 75.12 & $\mathbf{8 7 . 0 4}$ & BMP \\
Sep & 62.04 & 58.52 & 83.94 & 86.15 & 110.91 & 118.21 & 130.16 & $\mathbf{9 2 . 8 5}$ & BMP \\
Okt & 137.36 & 160.42 & 92.53 & 143.90 & 103.42 & 88.25 & 96.18 & $\mathbf{1 1 7 . 4 4}$ & MP \\
Nov & 81.42 & 78.52 & 116.86 & 69.49 & 136.96 & 138.06 & 114.75 & $\mathbf{1 0 5 . 1 5}$ & MP \\
Des & 177.43 & 178.45 & 109.53 & 160.43 & 90.35 & 135.81 & 104.05 & $\mathbf{1 3 6 . 5 8}$ & MP \\
\hline
\end{tabular}

BMP = Bukan Musim Penangkapan

MP = Musim Penangkapan

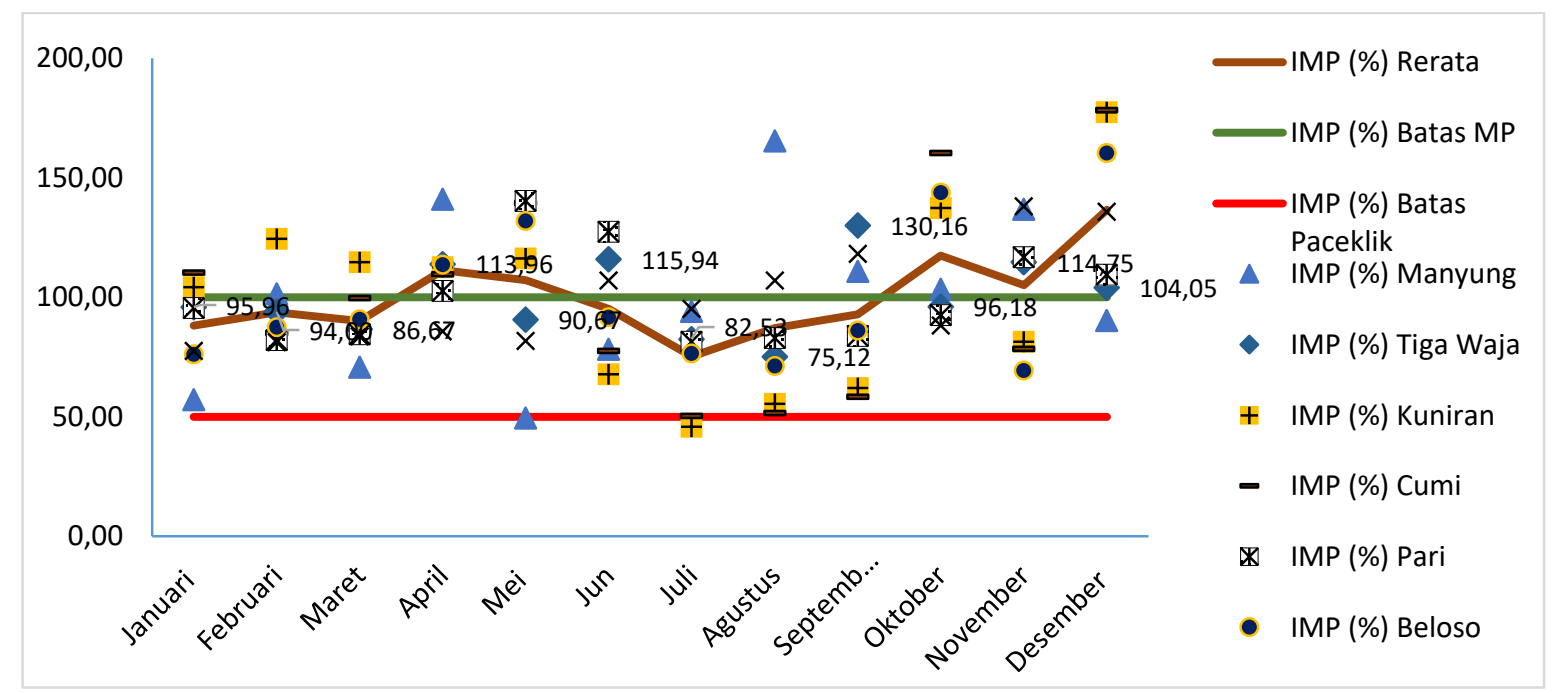

Gambar 1 Perbandingan IMP Beberapa jenis Ikan di Banyutowo.

Nilai rata-rata IMP tertinggi (136.58\%) di Banyutowo terjadi pada bulan Desember, dan merupakan musim puncak bagi ikan Kuniran (Upeneus sp), Beloso (Sauryda sp) dan Cumi-cumi (Loligo sp) dan musim penangkapan bagi ikan Pari (Dasyatis sp), Kuro (Eleutheronema tetradactylum), Tigawaja (Nibea sp). Kondisi ini juga dijumpai pada perairan Laut Jawa lainnya, dimana di Tegal puncak tertinggi musim Ikan Kuniran (Upeneus sp, Pari (Dasyatis sp), Beloso (Sauryda sp) dan Cumi-cumi (Loligo $s p$ ) juga terjadi pada bulan Desember (Imron 2008). Pada musim barat ini, meskipun curah hujan dan kecepatan angin tinggi namun diduga kelimpahan ikan tersebut cukup tinggi. Tingginya kelimpahan ikan diduga terkait dengan dengan 
tingginya kesuburan perairan pada musim ini, yang ditunjukkan oleh konsentrasi bentos, plankton dan larva pada musim Barat di perairan Jawa Tengah yang sangat tinggi (Priatna dan Natsir, 2008). Kesuburan perairan ini terkait dengan tingginya material dari sungai yang kaya nutrisi (Hendiarti et al., 2004, Hendriarti, 2005 dalam Prasetyo et al., 2017). Kecamatan Dukuh Seti dimana PPI Banyutowo berlokasi merupakan muara bagi beberapa sungai, yaitu Sungai Lenggi, Sungai Pengarep dan Sungai Ngarengan.

Kaitan kesuburan perairan dengan musim ikan demersal dan Cumi-cumi tidak secara langsung, namun berpengaruh terhadap rantai makanan. Saat kesuburan perairan meningkat, akan meningkatkan konsentrasi fitoplankton. Tingginya konsentrasi fitoplakton akan mengundang kehadiran pemakan fitoplankton, yaitu zooplankton dan ikan-ikan pelagis pemakan fitoplankton. Selanjutnya peningkatan jumlah zooplankton dan ikan-ikan pemakan fitoplanton ini akan mengundang kedatangan ikan-ikan pemangsa (karnivora), termasuk dalam hal ini ikan demersal dan cumi (Prasetiyo et al., 2014).

Bulan Agustus merupakan puncak musim penangkapan bagi ikan Manyung (Arius sp). Jika dikaitkan dengan pola angin muson, puncak musim ikan Manyung terjadi pada musim timur. Hal ini disebabkan oleh adanya proses divergensi di perairan utara Kecamatan Keling dan utara Kecamatan Donorojo, Kab. Jepara, yang merupakan wilayah penangkapan (fishing ground) nelayan Banyutowo. Proses tersebut menyebabkan nutrien yang berada di lapisan bawah terangkat dan meningkat konsentrasinya sehingga menyebabkan peningkatan kesuburan fitoplankton, diindikasikan dengan tingginya konsentrasi klorofil-a di wilayah tersebut.

Nilai IMP terendah ikan Bulan November merupakan saat dimana nilai IMP ikan Beloso (Sauryda sp) paling rendah (69.49\%). Hal ini diduga karena belum pulihnya sumber daya ikan setelah mengalami tekanan penangkapan yang tinggi pada bulan Oktober. Sementara itu, rendahnya nilai IMP Beloso di musim Timur dan musim Barat, diduga terkait dengan kondisi cuaca tidak menentu dan angin kencang, membuat nelayan mengurangi aktivitas penangkapan.

Hasil pengujian Anova untuk mengetahui perbedaan IMP beberapa jenis ikan berdasarkan bulan menunjukkan nilai $\mathrm{F}$ hitung (2.718247) lebih besar dibandingkan $\mathrm{F}$ tabel (1.937) sehingga $\mathrm{H}_{01}$ ditolak dan $\mathrm{H}_{11}$ diterima pada taraf kepercayaan 5\%. Dengan kata lain terdapat perbedaan nyata IMP berdasarkan bulan.

Hasil pengujian anova untuk mengetahui perbedaan IMP berdasarkan jenis ikan menunjukkan nilai $\mathrm{F}$ hitung (0.0000000163) lebih kecil dibandingkan $\mathrm{F}$ tabel (2.23948), sehingga $\mathrm{H}_{02}$ diterima dan $\mathrm{H}_{12}$ ditolak pada taraf kepercayaan 5\%, atau tidak terdapat perbedaan IMP berdasarkan jenis ikan. Meskipun demikian, patut dicermati bahwa hasil tangkapan ikan tidak hanya dipengaruhi oleh faktor tunggal, namun merupakan interaksi beberapa faktor yang saling terkait, diantaranya faktor alam (kesuburan perairan dan kondisi cuaca) serta faktor teknologi (jumlah trip kapal, jumlah kapal yang beroperasi serta alat tangkap yang digunakan) (Prasetyo et al. 2014).

Pola musim penangkapan ikan di Banyutowo berdasarkan jenis ikan dan alat tangkapnya dapat dilihat pada Tabel 4, yang memberikan gambaran mengenai musim penangkapan masing-masing jenis ikan dengan alat penangkapannya. Berdasarkan Tabel 4 tentang Pola Musim Penangkapan Ikan dan Jenis Alat Tangkap selama tujuh bulan dalam setahun (Januari, Februari, Maret, April, Mei, Oktober dan Desember) cantrang mampu menangkap lebih banyak jenis ikan yang sedang musim dibandingkan dengan gillnet. Selama empat bulan dalam setahun (Juni, Agustus, September dan Oktober) jumlah jenis ikan yang ditangkap oleh gillnet sama dengan cantrang. Pada bulan Juli baik cantrang maupun gillnet tidak cocok digunakan untuk menangkap ikan yang sedang musim di Banyutowo. Secara umum cantrang dapat menangkap lebih banyak jenis ikan dibandingkan dengan gillnet, sedangkan gillnet lebih selektif dalam menangkap jenis ikan dibandingkan cantrang. Wijayanto et al. (2019) menyatakan bahwa cantrang mempunyai fishing power yang lebih besar dibandingkan dengan gillnet. Cantrang juga mampu menangkap berbagai jenis dan ukuran ikan, termasuk ikan yang menjadi sasaran penangkapan gillnet. 
Tabel 4 Pola Musim Penangkapan Ikan di PPI Banyutowo Tahun 2009-2017 berdasarkan Jenis Ikan dan Alat Tangkap.

\begin{tabular}{|c|c|c|c|c|c|c|c|c|c|}
\hline \multirow{2}{*}{ Bulan } & \multicolumn{7}{|c|}{ Jenis Ikan } & \multicolumn{2}{|c|}{$\begin{array}{c}\text { Frekuensi MP Per Jenis } \\
\text { Alat Tangkap }\end{array}$} \\
\hline & Kuniran & Cumi & Pari & Beloso & Manyung & Kuro & Tiga Waja & $\begin{array}{c}\text { Cantrang } \\
\text { ( C ) }\end{array}$ & $\begin{array}{l}\text { Gillnet } \\
(G)\end{array}$ \\
\hline Jan & $\mathbf{C}$ & $\mathbf{C}$ & & & & & & 2 & 0 \\
\hline Feb & $\mathbf{C}$ & & & & $\mathrm{C} / \mathrm{G}$ & & & 2 & 1 \\
\hline Mar & $\mathbf{C}$ & & & & & & & 1 & 0 \\
\hline Apr & $\mathbf{C}$ & $\mathbf{C}$ & $\mathrm{C} / \mathrm{G}$ & $\mathbf{C}$ & $\mathrm{C} / \mathrm{G}$ & & $\mathrm{C} / \mathrm{G}$ & 6 & 3 \\
\hline Mei & $\mathbf{C}$ & $\mathbf{C}$ & $\mathrm{C} / \mathrm{G}$ & $\mathbf{C}$ & & & & 4 & 1 \\
\hline Jun & & & $\mathrm{C} / \mathrm{G}$ & & & $\mathrm{C} / \mathrm{G}$ & $\mathrm{C} / \mathrm{G}$ & 3 & 3 \\
\hline Jul & & & & & & & & 0 & 0 \\
\hline Ags & & & & & $\mathrm{C} / \mathrm{G}$ & $\mathrm{C} / \mathrm{G}$ & & 2 & 2 \\
\hline Sep & & & & & $\mathbf{C} / \mathbf{G}$ & $\mathrm{C} / \mathrm{G}$ & $\mathrm{C} / \mathrm{G}$ & 3 & 3 \\
\hline Okt & $\mathbf{C}$ & $\mathbf{C}$ & & $\mathbf{C}$ & $\mathbf{C} / \mathbf{G}$ & & & 4 & 1 \\
\hline Nov & & & $\mathrm{C} / \mathrm{G}$ & & C/G & $\mathrm{C} / \mathrm{G}$ & C/G & 4 & 4 \\
\hline Des & $\mathbf{C}$ & $\mathbf{C}$ & $\mathrm{C} / \mathrm{G}$ & $\mathbf{C}$ & & $\mathrm{C} / \mathrm{G}$ & $\mathbf{C} / \mathbf{G}$ & 6 & 2 \\
\hline
\end{tabular}

Keterangan :
C : Musim Penangkapan Ikan, menggunakan alat tangkap cantrang
G : Musim Penangkapan Ikan, menggunakan alat tangkap gillnet
C/G : Musim Penangkapan Ikan, menggunakan cantrang atau gillnet
: Bukan musim penangkapan ikan

\section{Efektivitas Penggantian Alat Tangkap Cantrang dengan Gillnet Millenium}

Penerima penggantian cantrang menjadi gillnet millennium di Banyutowo berjumlah 18 orang, seluruhnya berasal dari KUB Mina Lestari. Wawancara dan pengisian kuesioner dilakukan terhadap 16 responden (88.89\%). Usia responden berkisar antara 30-65 tahun. Pendidikan terakhir SD sebanyak 13 orang $(81,3 \%)$, SMP sebanyak 2 orang (12.5\%), SMA sebanyak 1 orang $(6.3 \%)$. Seluruh reponden telah menikah. Saat pelaksanaan penelitian, 11 orang nelayan (68.8\%) masih memiliki 1 unit cantrang, 4 orang nelayan masih memiliki 2 unit cantrang dan 1 orang responden masih memiliki 3 cantrang. 11 orang reponden (68.9\%) telah menggunakan cantrang selama lebih dari 10 tahun. 5 orang responden $(31.1 \%)$ telah menggunakan cantrang selama 2-5 tahun.

Untuk indikator identifikasi dan verifikasi pada tahap proses, dinilai berdasarkan analisis terhadap dokumen hasil identifikasi dan verifikasi calon penerima penggantian alat tangkap cantrang dari Dinas Kelautan dan Perikanan Kabupaten Pati tahun 2016.

\section{Evaluasi Proses}

Hasil analisis menunjukkan nilai rata-rata sebesar $47.92 \%$, artinya tidak terjadi efektivitas pada proses penggantian alat tangkap cantrang menjadi gillnet. Tingkat efektivitas ini sangat dipengaruhi oleh rendahnya pengetahuan nelayan terhadap tujuan penggantian alat tangkap serta kurangnya pendampingan dan pemantauan. Meskipun variabel kegiatan sosialisasi menunjukkan hasil cukup efektif. Sosialisasi tersebut belum sepenuhnya memberikan pemahaman tujuan kepada para nelayan penerima bantuan. 
Tabel 5 Analisis Efektivitas Tahapan Proses Penggantian Cantrang dengan Gillnet Millenium.

\begin{tabular}{|c|c|c|c|c|c|}
\hline No. & Indikator Evaluasi Proses & Target & Realisasi & $\begin{array}{l}\text { Efektivitas } \\
(\%)\end{array}$ & Kategori \\
\hline 1 & $\begin{array}{l}\text { Identifikasi dan validasi calon penerima } \\
\text { sesuai ketentuan }\end{array}$ & 18 & 18 & $100.00 \%$ & Sangat Efektif \\
\hline 2 & Pengetahuan terhadap tujuan & 16 & 2 & $12.50 \%$ & $\begin{array}{l}\text { Sangat tidak } \\
\text { efektif }\end{array}$ \\
\hline 3 & Sosialisasi & 16 & 9 & $56.25 \%$ & Cukup efektif \\
\hline 4 & Informasi alternatif alat tangkap pengganti & 16 & 9 & $56.25 \%$ & Cukup efektif \\
\hline 5 & Pelatihan & 16 & 9 & $56.25 \%$ & Cukup efektif \\
\hline 6 & Pendampingan atau pemantauan & 16 & 1 & $6.25 \%$ & $\begin{array}{c}\text { Sangat tidak } \\
\text { efektif }\end{array}$ \\
\hline & Rata-rata & & & $47.92 \%$ & Tidak Efektif \\
\hline
\end{tabular}

Indikator identifikasi dan validasi calon penerima dilakukan melalui analisis dokumen, selanjutnya dibandingkan dengan kriteria yang diatur dalam Petunjuk Teknis Bantuan Sarana Perikanan Tangkap Tahun 2016. Hasil identifikasi dan validasi dokumen tersebut menunjukkan bahwa identifikasi dan validasi calon penerima telah sesuai dengan petunjuk teknis (KKP, 2016).

Pemantauan terhadap pelaksanaan penggantian alat tangkap, merupakan salah satu variabel penting dalam keberhasilan kegiatan antara lain mengetahui kesesuaian pelaksanaan dibandingkan dengan rencana, dan dapat segera mengetahui penyebab ketidaksesuaian program sehingga dapat disusun langkah perbaikan (Arikunto dan Jabar, 2008). Penilaian responden terhadap terhadap pemantauan sangat tidak efektif, yaitu hanya $6,25 \%$. Sebagian besar responden menyampaikan bahwa tidak ada petugas yang melakukan pemantauan setelah penggantian alat tangkap, sehingga permasalahan-permasalahan yang terjadi lambat diketahui, dan lambat ditindaklanjuti.

\section{Evaluasi Keluaran}

Analisis terhadap penggantian cantrang dengan gillnet millenium menunjukkan nilai rata-rata 33,75\%, atau sangat tidak efektif. Variabel pemilihan gillnet millennium sebagai alat tangkap pengganti cantrang menunjukkan tingkat efektifitas $25 \%$ (sangat tidak efektif). Hasil ini berbeda dengan hasil indikator identifikasi dan verifikasi pada tahapan proses yang menunjukkan hasil sangat efektif. Berdasarkan dokumen, seluruh calon penerima memilih gillnet millennium sebagai pengganti cantrang, namun berdasarkan analisis persepsi sebagian besar calon penerima menjawab tidak memilih gillnet millennium. Setelah ditelusuri lebih lanjut, hal ini disebabkan pada saat mengusulkan secara tertulis alat tangkap yang dipilih, anggota kelompok mengikuti saran pengurus kelompok untuk memilih gillnet millennium sebagai alat tangkap pengganti cantrang. Kondisi ini menunjukkan kurang tepatnya metode identifikasi, dimana pemilihan jenis alat tangkap pengganti hanya pada berdasarkan pada keinginan dan minat nelayan, tanpa dilengkapi informasi memadai mengenai kondisi dan potensi kelimpahan sumber daya ikan di suatu perairan.

Variabel pemanfaatan alat tangkap pengganti menunjukkan nilai 37.5\%, (sangat tidak efektif) karena tingkat pemanfaatan gillnet millennium cukup rendah. Hasil wawancara dengan nelayan penerima diketahui hasil tangkapan menggunakan gillnet millennium sangat sedikit, akibatnya sebagian besar nelayan penerima alat tangkap tersebut kembali menggunakan cantrang. Sebagian kecil nelayan penerima tetap bertahan menggunakan gillnet millennium dengan melakukan modifikasi terhadap alat tangkap tersebut, yaitu menyatukan beberapa gillnet millennium atau membagi dua gillnet millennium secara horizontal kemudian disatukan. Penggunaan alat tangkap ini tidak rutin dan hasil tangkapannya belum tercatat dengan baik. Meskipun demikian, perlu diapresiasi upaya para nelayan tersebut dengan keyakinan bahwa hasil tangkapan ikan akan meningkat seiring dengan semakin mahirnya mereka dalam menggunakan alat tangkap tersebut. Hal ini terkait erat dengan hasil analisis terhadap variabel kemampuan merakit dan mengoperasikan gillnet 
millenium yang menunjukkan nilai $43.75 \%$ (tidak efektif). Diketahui dari hasil pelatihan bahwa sebagian besar nelayan belum mampu/ tidak mau merakit alat tangkap dan atau mengoperasikannya.

Penolakan untuk menggunakan oleh sebagian besar nelayan penerima maupun adanya upaya sebagian kecil nelayan penerima gillnet millennium disebabkan adanya ketidaksesuaian alat tangkap tersebut dengan armada penangkapan yang digunakan. Perahu untuk mengoperasikan cantrang berlunas lebar dan ukurannya pendek (Nababan et al., 2018), sedangkan untuk mengoperasikan gillnet millennium diperlukan perahu yang lebih kecil dibandingkan perahu untuk mengoperasikan cantrang.

Tabel 6 Analisis Efektivitas Tahapan Keluaran Penggantian Cantrang dengan Gillnet Millenium.

\begin{tabular}{|c|c|c|c|c|c|}
\hline No. & Indikator Evaluasi Proses & Target & Realisasi & Efektivitas (\%) & Kategori \\
\hline 1 & $\begin{array}{l}\text { Pemilihan gillnet millennium } \\
\text { sebagai alat tangkap pengganti }\end{array}$ & 16 & 4 & $25.00 \%$ & Sangat tidak efektif \\
\hline 2 & $\begin{array}{l}\text { Pemanfaatan alat tangkap } \\
\text { pengganti }\end{array}$ & 16 & 6 & $37.50 \%$ & Sangat tidak efektif \\
\hline 3 & $\begin{array}{l}\text { Kemampuan merakit dan } \\
\text { mengoperasikan gillnet } \\
\text { millenium }\end{array}$ & 16 & 7 & $43.75 \%$ & Tidak efektif \\
\hline 4 & $\begin{array}{l}\text { Kesesuaian kapal/ perahu } \\
\text { untuk mengoperasikan gillnet } \\
\text { millenium }\end{array}$ & 16 & 0 & $0.00 \%$ & Sangat tidak efektif \\
\hline 5 & $\begin{array}{l}\text { Kesesuaian gillnet millenium } \\
\text { untuk digunakan di perairan } \\
\text { sekitar Banyutowo }\end{array}$ & 16 & 10 & $62.50 \%$ & Cukup Efektif \\
\hline & Rata-rata & & & $33.75 \%$ & Sangat Tidak efektif \\
\hline
\end{tabular}

\section{SIMPULAN}

Berdasarkan kondisi biofisik perairan dan data hasil tangkapan, diketahui bahwa Cantrang dapat menangkap lebih banyak jenis ikan dibandingkan dengan gillnet. Hal ini disebabkan gillnet lebih selektif dalam menangkap jenis ikan dibandingkan cantrang. Artinya kebijakan penggantian cantrang dengan gillnet millennium sudah sesuai dan mendukung pencapaian tujuan pembangunan kelautan dan perikanan secara berkelanjutan. Meskipun demikian, agar upaya penggantian alat tangkap ini dapat mencapai tujuannya secara optimal, dibutuhkan upaya penyempurnaan program sebagai berikut: a) Mempertimbangkan kesesuaian antara alat tangkap dengan armada penangkapan yang digunakan; b) Pendampingan yang lebih daripada sekedar memberi pelatihan kepada para nelayan penerima program, sehingga mereka dapat menguasai dengan baik penggunaan alat tangkap pengganti yang diberikan.

\section{DAFTAR PUSTAKA}

[KKP] Kementerian Kelautan dan Perikanan. 2015. Peraturan Menteri Kelautan dan Perikanan No. 2 Tahun 2015 tentang Pelarangan Alat Penangkapan Ikan Pukat Hela dan Pukat Tarik (seine Nets). Jakarta (ID) [internet]. [diunduh $\quad$ pada $2016 \quad$ Jan 20 ] tersedia http://infohukum.kkp.go.id/index.php/hukum/download/645/?type_id=1

[KKP] Kementerian Kelautan dan Perikanan. Direktorat Jenderal Perikanan Tangkap. 2016. Petunjuk Teknis Bantuan Sarana Perikanan Tangkap Tahun 2016. Jakarta. (ID): Kementerian Kelautan dan Perikanan.

Arikunto S, Jabar CSA. 2008. Evaluasi Program Pendidikan. Pedoman Teoritis Praktis Bagi Mahasiswa dan Praktisi Pendidikan. Edisi Kedua. Jakarta (ID): Bumi Aksara.

Badrudin, Aisyah, Ernawati T. 2011. Kelimpahan stok sumber daya ikan demersal di Perairan Sub Area Laut Jawa. Jurnal Penelitian Perikanan Indonesia. 
https://doi.org/http://dx.doi.org/10.15578/jppi.17.1.2011.11-21.

Budiani, NW. 2009. Efektivitas program penanggulangan pengangguran karang taruna "Eka Taruna Bhakti" Desa Sumerta Kelod Kecamatan Denpasar Timur Kota Denpasar. Jurnal Ekonomi dan Sosial. I N P U T. 2(1): 49-57.

Dajan A. 1986. Pengantar Metode Statistik Jilid I. Jakarta (ID): LP3ES.

Damora, A., Ernawati, T. 2011. Beberapa aspek biologi ikan beloso (Saurida micropectoralis) di perairan utara Jawa Tengah. Bawal. 3: 363-367. https://doi.org/10.15578/bawal.3.6.2011.363-367.

Hendiarti N, Siegel H, Ohde T. 2004. Investigation of different coastal processes in Indonesian waters using SeaWiFS data. Deep Sea Research Part II: Tropical Studies in Oceanography. 51 (1-3): 85-97. https://doi.org/10.1016/J.DSR2.2003.10.003.

Hermanto D, Kusumastanto T, Adrianto L, Supartono. 2019. Pengelolaan sumberdaya perikanan tangkap berbasis daya dukung lingkungan perairan Di WPPNRI 711. Jurnal Pengelolaan Sumberdaya Alam Dan Lingkungan. 9(1): 105-113. https://doi.org/10.29244/jpsl.9.1.

Hidayat EF, Pujiyati S, Suman A, Hestirianoto T. 2019. Estimating potential zones of pelagic fish in WPPNRI 711 (Study case of Natuna Sea). Jurnal Pengelolaan Sumberdaya Alam Dan Lingkungan. 9(1): 92-96. https://doi.org/10.29244/jps1.9.1.92-96.

Imron M. 2008. Pemanfaatan Sumberdaya Perikanan Demersal Yang Berkelanjutan Di Perairan Tegal Jawa Tengah (Institut Pertanian Bogor). Retrieved from https://repository.ipb.ac.id/bitstream/handle/123456789/40993/2008mim.pdf?sequence=15\&isAllowed $=\mathrm{y}$.

Nababan BO, Solihin A, Christian Y. 2018. Dampak Sosial Ekonomi Kebijakan Larangan Pukat Hela dan Pukat Tarik di Pantai Utara Jawa. Bogor(ID): Indonesia.

Prasetyo BA, Hartoko A, Hutabarat S. 2014. Sebaran spasial Cumi-cumi (Loligo Spp.) dengan variabel suhu permukaan laut dan klorofil-a data Satelit Modis Aqua di Selat Karimata Hingga Laut Jawa. Jurnal Management of Aquatic Resources. 3(1): 51-60.

Prasetyo DA, Kunarso K, Satriadi A. 2017. Keterkaitan varibilitas angin terhadap perubahan kesuburan dan potensi daerah penangkapan ikan di Perairan Jepara. Jurnal Oseanografi. 6(1): 158-164.

Priatna A, Natsir M. 2008. Pola sebaran ikan pada musim barat dan peralihan di Perairan Utara Jawa Tengah. Jurnal Penelitian Perikanan Indonesia. 14(1): 67-76.

Simarmata R, Boer M, Fahrudin A. 2014. Analisis sumberdaya Ikan Tembang (Sardinella fimbriata) di Perairan Selat Sunda yang didaratkan di PPP Labuan, Banten. Marine Fisheries. 5(2): 149-154.

Triarso I. 2013. Potensi dan peluang pengembangan usaha perikanan tangkap di Pantura Jawa Tengah. Jurnal Saintek Perikanan. 8(2): 6-17.

Wijayanto D, Sardiyatmo, Setyanto I, Kurohman F. 2019. Bioeconomic analysis of the impact of 'cantrang' (Danish seine) toward gill net in Pati regency, Indonesia. AACL Bioflux. 12(1):25-33.

Wirawan. 2016. Evaluasi Teori, Model, Metodologi, Standar, Aplikasi dan Profesi (Edisi Revisi). Jakarta. (ID): Rajagrafindo Persada.

Zubainarni N, Yani,A. Faradissa. 2016. Kajian Valuasi Dampak Ekonomi dan Sosial Pelarangan Alat Tangkap Cantrang di Jawa Tengah. Bogor (ID) : Agro Maritim. 